\title{
A TRIBUTE TO PROF. DR. FARUK JOSÉ NOME AGUILERA ON HIS 60th BIRTHDAY
}

\author{
Lavinel G. Ionescu $^{\text {a,b }}$, Luis Alcides Brandini De Boni ${ }^{\mathrm{c}}$ and Eduardo Goldani ${ }^{\mathrm{c}}$ \\ SCIENCO Scientific Consulting Services ${ }^{\text {a }}$ \\ Huntington Beach, California, USA \\ and \\ Sarmisegetusa Research Group ${ }^{\mathrm{b}}$ \\ Santa Fe, New Mexico, USA \\ TCHE QUIMÍCA Ltda. ${ }^{c}$ \\ Porto Alegre, RS, BRASIL
}

\begin{abstract}
Prof. Faruk José Nome Aguilera was born in Linares, Chile on May 29, 1947. He graduated in biochemistry from the University of Chile in 1971, obtained the Ph.D. Degree in Chemistry from Texas A\& M University in 1976 and has been a faculty member at the Universidade Federal de Santa Catarina, Florianópolis, Brazil since 1977. His main research interests deal with catalysis and mechanisms of organic reactions in solution. He has trained approximately eighty research scientists including more than forty master and twenty doctoral students and has published about three hundred scientific articles. Prof. Faruk is a member of the Brazilian Academy of Science.
\end{abstract}

KEY WORDS : History of chemistry. Organic Reactions Mechanism, Science in Brazil

\section{RESUMO}

Prof. Faruk José Nome Aguilera nasceu em Linares, Chile em 29 de Maio de 1947. Ele se formou em bioquímica na Universidad de Chile e obteve o grau de Ph.D. em Química da Texas A\&M University em 1976 e faz parte do corpo docente da Universidade Federal de Santa Catarina em Florianópolis, Brasil desde 1977. Suas atividades principais de pesquisa tratam de catálise e mecanismos de reações orgânicas em solução. Ele preparou mais de oitenta pesquisadores, incluindo mais de quarenta alunos de mestrado e vinte de dourado e publicou aproximadamente trezentos trabalhos científicos. O Prof. Faruk é membro da Academia Brasileira de Ciências.

PALAVRAS-CHAVE: História da Química, Mecanismo de reações orgânicas, Ciência no Brasil. 
Faruk José Nome Aguilera was born in Linares, Chile on May 30, 1947. He was the youngest of eleven siblings, six boys and five girls.

His father, José Maria Nome Gonzalez, originally from Damascus, Syria, settled in Chile at the beginning of the last century (1910) and with time became a very successful merchant.

His mother, Mercedes Aguilera, a true matriarch, was a member of a well to do Chilean family from the Maule Region.

Prof. Faruk attended primary and secondary school in Linares and as a child and as the youngest brother received a lot of special attention from all his family.

Linares is a very pleasant city located in the Maule Region in the center of the country, on the fertile central plain, about $300 \mathrm{~km}$ south of Santiago and $50 \mathrm{~km}$ south of Talca. The Cordillera of the Andes is not far away to the east. It was founded by Ambrosio O'Higgins, Viceroy of Peru in 1794. At the present, it has a population of about 80,000 people and it is an active agricultural, industrial, commercial and service center. It is the home of the Artillery School of the Chilean Army. One of its main attractions is the Cathedral Church of San Ambrosio de Linares and its square. It was inspired by the Basilica of Santo Ambrosio, Milano, Italy, and among the monuments of the central square there are some lions that in the more distant past adorned the main square of Lima, Peru.

The city counts among its natives important statesmen, politicians, poets, writers, musicians, scientists and intellectuals. We mention in passing, Abate Molina (Juan Ignacio Molina), priest, naturalist and father of Chilean science; Pablo Neruda, famous poet and Noble Prize winner and two former presidents of the country, Carlos Ibañez del Campo and Arturo Alessandri Palma.

Prof. Faruk began studies at the University of Chile, Santiago at the age of sixteen and graduated in biochemistry in 1971. He continued his studies at the graduate level at Texas A\&M University and obtained the Ph.D. Degree in Chemistry in 1976. His research advisor was Prof. Janos H. Fendler.

In 1977 Prof. Faruk Nome joined the faculty of Universidade Federal de Santa Catarina (UFSC), in Florianópolis, Brazil, where he is still active at the present time and holds the position of Full Professor of Chemistry.

During his 30-year tenure as Professor at the Federal University of Santa Catarina (UFSC), Dr. Faruk Nome participated of a wide number of committees and councils at the departmental, university, state and national levels. Among them we cite the Graduate Committee in Chemistry, Superior Council of Science and Technology of the State of Santa Catarina (FUNCITEC), Brazilian National Research Council (CNPq) and the Brazilian Commission for Improvement of Higher Education (CAPES). 


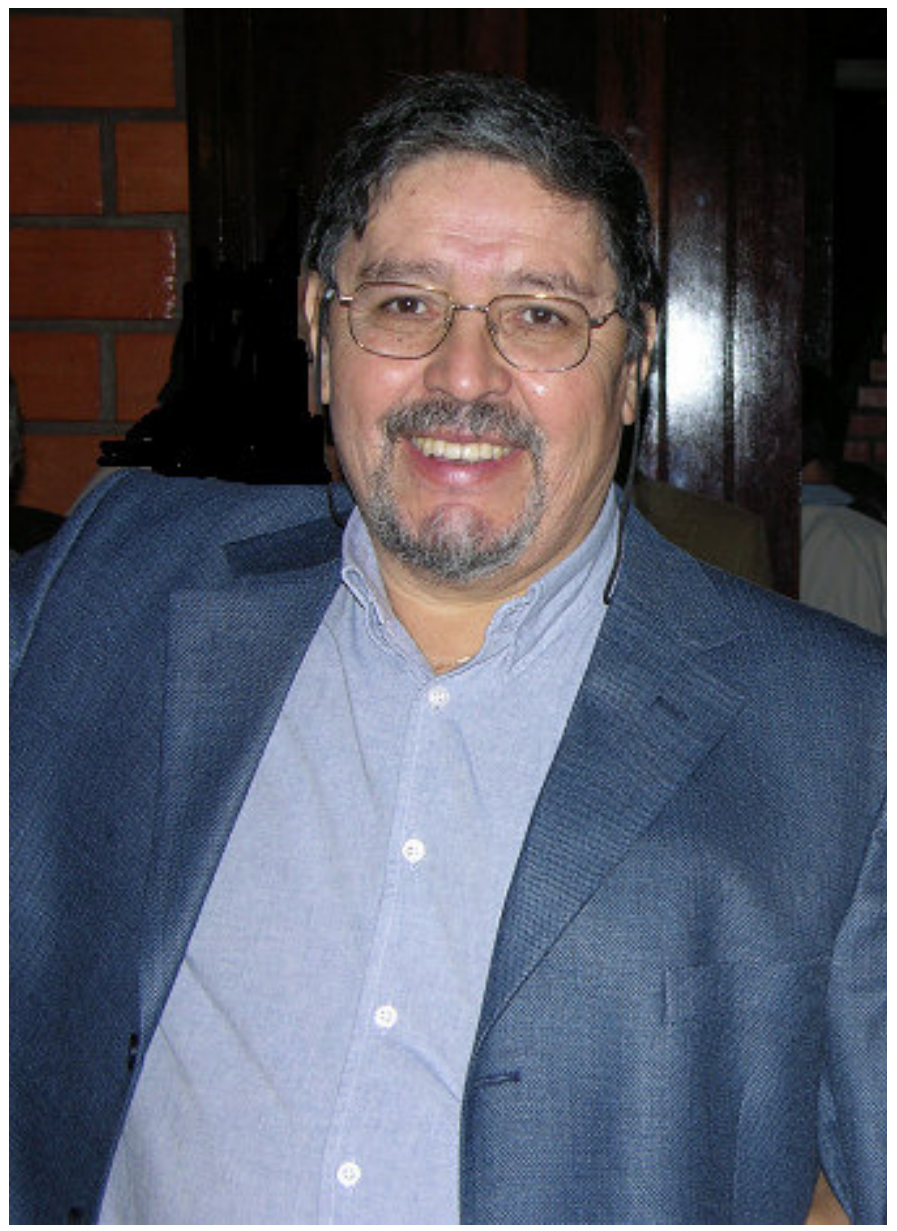

PROF. DR. FARUK JOSÉ NOME AGUILERA

Prof. Faruk's main research interests deal with catalysis and mechanisms of organic reactions in solution. One aspect of his work involves the development of catalysts for the hydrolysis of phosphate and sulfate esters, as well as nucleic acids, amides and other esters of biological interest. Another aspect deals with the effect of colloidal aggregates and artificial enzymes on organic reactions in solution. In particular, he is interested in the effect of dendrimers, functional polymers and anionic, cationic, neutral and zwitterionic micelles on organic reactions with special emphasis on reaction rates, reactivity, equilibrium and incorporation of substrates.

We (LGI) first met Prof. Faruk Nome Aguilera in July of 1978, soon after our arrival in Florianópolis, where we went mainly with the purpose to help establish the Master Degree Program in Physical Chemistry. Soon afterwards we collaborated doing research work on micellar catalysis, decomposition of pesticides and micelle formation.

At the time, Prof. Faruk was a young and enthusiastic scientist, full of energy, dreams and expectations. 
He had the option to return to his native Chile, set up a chemical laboratory in Linares, where his brothers reserved a whole floor of a tall building in the center of the town, be close to his family or accept a position as a faculty member at the University of Chile. He decided to stay in Florianópolis and be a pioneer in science in Santa Catarina.

The graduate program was not actually in Physical Chemistry. It consisted really of two programs under the same roof, one in Chemistry, the other in Physics. The Physics Department in Florianópolis, that was better established at the time, had all its plans for beginning a graduate program undermined by physicists at the Universidade Federal do Rio Grande do Sul (UFRGS) in Porto Alegre, who felt more comfortable without any competition in Southern Brazil.

During the initial stages of the program we mention the substantial and fundamental effort and contribution of Profs. John Dale Gault (USA), Ted Ray Taylor (USA), Subramania Jayaraman (India) and Joel Louis Rene Muzart (France) in Physics and Prof. Faruk (Chile), Juan Jacob Eduardo Humeres Allende (Chile) and ourself (LGI-USA) in Chemistry. A few years later we were joined by Prof. Rosendo Augusto Yunes from Argentina. The research activity in physics dealt mainly with liquid crystals and phase transitions and in chemistry with organic reactions, surfactants and micelles.

Among the Brazilians who were students in the beginning and later made significant contributions, we cite Profs. Ademir Neves, Bruno Szpoganicz, Eduardo Stadler and Eduardo Pinheiro in Chemistry and Luiz Taylor Silveira Siedler, Abio Valeriano de Andrades Pinto and Antônio Rogério de Souza in Physics. Worthy of special note are the efforts and contributions of Graça Hoeller, secretary of the Graduate Program from the beginning to the present and Jadir Caminatti who has been helping with administrative tasks since 1981 .

The Graduate Program in Physical Chemistry terminated officially in 1991 with the simultaneous establishment of two separate Doctoral Programs, one in Chemistry and the other one in Physics. At the present, both of them are considered of excellent quality and are widely respected throughout Brazil. A total of one hundred ninety nine (199) master theses were approved during the duration of the Graduate Program in Physical Chemistry, more or less evenly divided between chemistry and physics

The new program in chemistry led to the graduation of two hundred and fifty eight (258) master students and one hundred and ninety three (193) doctoral students from 1990 to the present date.

In retrospect, it is relatively easy to see what Prof. Dr. Faruk José Nome Aguilera accomplished in thirty years of effort and hard work in Florianópolis, Brazil. We may only conjecture what might have happened if he had returned to his native Chile. Prof. Faruk Nome might have been a very successful businessman, owner of a chain of chemical laboratories scattered throughout Chile, widely respected scientist and educator or Minister of Education, Science 
and Technology. He could have spent hundreds of weekends resting and reflecting at Pesce Rey, a mountain resort in the Andes, property of his family.

We salute Prof. Dr. Faruk José Nome Aguilera on the occasion of his sixtieth birthday, pay our modest tribute to him as a scientist, colleague and friend and congratulate him for his effort and accomplishments during the last thirty years and convey him the best wishes of good health, happiness and success for the days to come.

\section{SOME REPRESENTATIVE PUBLICATIONS}

1. FERREIRA, V B N; BORTOLUZZI, A J; KIRBY, A J; NOME, F . 2-Allyloxy5-chlorobenzoic acid. Acta Crystallographica. Section E, v. E63, p. o2981$02981,2007$.

2. SAPELLI, E; BRANDÃO, T A S ; FIEDLER, H. D. ; NOME, F . Fluorescence of $\mathrm{Zn}$ (II) 8-hydroxyquinoline complex in the presence of aqueous micellar media: The special cetyltrimethylammonium bromide effect. Journal of Colloid and Interface Science, v. 314, p. 214-222, 2007.

3. BRANDÃO, T A S; ORTH, Elisa S; ROCHA, Willian R ; BORTOLUZZI, A J ; BUNTON, C. A. ; NOME, F . Intramolecular General Acid Catalysis of the Hydrolysis of 2-(2'-Imidazolium)phenyl Phosphate, and Bond LengthReactivity Correlations dor Reactions of Phosphate Monoester Monoanions. Journal of Organic Chemistry, v. 207, p. 3800-3807, 2007.

4. Marte, L ; BEBER, R C ; Farrukh, M.A. ; Micke, G.A ; Costa, A.C.O. ; Gillitt, N.D. ; BUNTON, C. A. ; Profio, P.D. ; SAVELLI, G. ; NOME, F . Specific Anion Binding to Sulfobetaine Micelles and Kinetics of Nucleophilic Reactions. The Journal of Physical Chemistry. B, Condensed Matter, Materials, Surfaces, Interfaces \& Biophysical, v. 111, p. 1-8, 2007.

5. FRITZEN, M B; SOUZA, A J; SILVA, T A G; SOUZA, L; NOME, R A; FIEDLER, H ; NOME, F . Distribution of hexavalent $\mathrm{Cr}$ species across the clay mineral surface water interface. Journal of Colloid and Interface Science, USA, v. 296, p. 465-471, 2006.

6. FRASSON, C M L ; BRANDÃO, T A S ; ZUCCO, C ; NOME, F . Solvent effect and proton inventory in the hydrolysis of p-methylphenyl trichloroacetate . Journal of Physical Organic Chemistry, USA, v. 19, n. 2, p. 143-147, 2006.

7. FONSECA, G S ; DOMINGOS, J B ; NOME, F ; DUPONT, J . On the kinetics of iridium nanoparticles formation in ionic liquids and olefin hydrogenation. Journal of Molecular Catalysis A-Chemical, USA, v. 248, p. 10-16, 2006.

8. MELLO, R S; BEDENDO, G C; NOME, F ; FIEDLER, H D ; LARANJEIRA, M C M . Preparation of chitosan membranes for filtration and concentration of compounds under high pressure process. Polymer Bulletin, Germany, v. 56, p. 447-454, 2006.

9. SILVEIRA, G P ; NOME, F ; GESSER, J C ; SA, M M ; TERENZI, H . Estratégias utilizadas no combate a resistência bacteriana. Química Nova, Brasil, v. 29, n. 4, p. 844-855, 2006. 
10. ONOFRIO, A B; JÄGER, e ; BRANDÃO, T A S ; BORTOLUZZI, A J ; NOME, $\mathrm{F}$. N-(o-Carboxybenzoyl)-L-Leucinate methyl ester. Acta Crystallographica Section C-Crystal Structure Communications, United Kingdom, v. c62, p. 237-239, 2006.

11. KIRBY, Anthony J ; DAVIES, John e ; BRANDÃO, Tiago A S ; SILVA, Pedro Luiz Ferreira da ; ROCHA, Willian R ; NOME, F . Hydroxylamine as an Oxygen Nucleophile. Structure and Reactivity of Ammonia Oxide. Journal of the American Chemical Society, USA, v. 128, p. 12374-12375, 2006.

12. KIRBY, A J ; LIMA, M F ; SILVA, D da ; ROUSSEV, Christo D ; NOME, F . Efficient intramolecular general acid catalysis of nucleophilic attack on a phosphodiester. Journal of the American Chemical Society, USA, v. 128, n. 51, p. 16944-16952, 2006.

13. NOME, F . Preface. Journal of Physical Organic Chemistry, England, v. 19, n. 11, p. 699-699, 2006.

14. LONGHINOTTI, e ; DOMINGOS, J B ; SILVA, P L F da ; SZPOGANICZ, B NOME, F . Bis(2,4-dinitrophenyl) Phosphate Hydrolysis Mediated by Lanthanide Ions. Journal of Physical Organic Chemistry, USA, v. 18, n. 2, p. 167-172, 2005.

15. VARGAS, L V ; SAND, J ; BRANDÃO, T A S ; FIEDLER, H D ; QUINA, F H ; NOME, F . Determination of environmentally important metal ions by fluorescence quenching in anionic micellar solution.. Analyst, England, v. 130, n. 2, p. 242-246, 2005.

16. LONGHINOTTI, e ; DOMINGOS, J B ; SZPOGANICZ, B ; NEVES, A ; NOME, F . Catalytic effect of a dinuclear [Fe2III $(\mathrm{OH})(\mathrm{OH} 2)]$ complex in the hydrolysis of bis(2,4-dinitrophenyl) phosphate.. Inorganica Chimica Acta, England, v. 358, n. 6, p. 2089-2092, 2005.

17. BRANDÃO, T A S ; PRIEBE, J P ; DAMASCENO, A S ; BOTOLUZZI, A J ; KIRBY, A J ; NOME, F . Bond Length-Reactivity Correlations for Sulfate Monoesters. The Crystal Structure of Potassium 4-Nitrophenyl Sulfate, C6H4KNO6S.. Journal of Molecular Structure, Great Britain, v. 734, p. 205$209,2005$.

18. WESTRUP, J L ; FRITZEN, Maurícia Beddin ; SOUZA, A J ; BEDENDO, Gizelle C ; NOME, F ; FIEDLER, H D . Sorption and Desorption of Cd(II) at the Clay Particle-Water Interface and its Relevance to the Distribution of Metal Ions in Natural Systems. Journal of the Brazilian Chemical Society, Campinas, v. 16, n. 5, p. 982-987, 2005.

19. KIRBY, A J ; DUTTAROY, Neil ; SILVA, Davi da ; GOODMAN, Jonathan M ; LIMA, Marcelo F ; ROUSSEV, Christo D ; NOME, F . Intramolecular general acid catalysis of phosphate transfer. Nucleophilic attack by oxyanions on the phosphate group.. Journal of the American Chemical Society, USA, v. 127, p. 7033-7040, 2005.

20. KIRBY, A J ; GESSER, J. C. ; HOLLFELDER, F ; PRIEBE, J P ; NOME, F . Efficient intramolecular general acid catalysis of sulfate transfer. Nucleophilic attack by oxyanions on the SO3- group. Canadian Journal of Chemistry-Revue Canadienne de Chimie, Canadá, v. 83, n. 9, p. 1629-1636, 2005.

21. NOME, F ; ONOFRIO, A B ; SOLDI, M S ; SOLDI, V ; JOUSSEF, A C . Thermal degradation of $\mathrm{N}$-(o-carboxybenzoyl)-L-amino acids. Thermochimica Acta, USA, v. 413, p. 47-52, 2004. 
22. NOME, F; BRANDÃO, T A S; MAGRO, J D; CHIARADIA, L D; NASCIMENTO, M G ; TATO, J V ; YUNES, R A . Concerning the Catalytic and Inhibitory Effects of -Cyclodextrin on the Hydrolysis of Benzoic Anhydride.. Journal of Physical Organic Chemistry, USA, v. 17, n. 5, p. 370375, 2004.

23. BEBER, R C; BUNTON, C. A.; SAVELLI, G.; NOME, F. Incorporation and Differential Reactivity of Anions in Zwitterionic Sulfobetaine Micelles. Progress in Polymer Science, Germany, v. 128, p. 249-255, 2004.

24. KIRBY, A J ; LIMA, M F ; SILVA, D da ; NOME, F . Nucleophilic Attack by Oxyanions on a Phosphate Monoester Dianion: The Positive Effect of a Cationic General Acid.. Journal of the American Chemical Society, USA, v. 126, p. 1350-1351, 2004.

25. FIEDLER, H D ; WESTRUP, J L ; SOUZA, A J ; PAVEI, A D ; CHAGAS, C $\mathrm{U}$; NOME, F . Cd(II) Determination in the Presence of Aqueous Micellar Solutions.. Talanta, USA, v. 64, p. 190-195, 2004.

26. MARTENDAL, A ; DIAS, R ; NOME, F ; ZUCCO, C . Synthesis of 5-alkyl-2,3dihydro-1,4benzodioxins. Synthetic Communications, USA, v. 34, n. 13, p. 2487-2498, 2004.

27. DOMINGOS, J B ; LONGHINOTTI, e ; BRANDÃO, T A S ; BUNTON, C A ; SANTOS, L S ; EBERLIN, M N ; NOME, F . Mechanisms of Nucleophilic Substitution Reactions of Methylated Hydroxylamines with Bis(2,4dinitrophenyl) Phosphate. Mass Spectrometric Identification of Key Intermediates. Journal of Organic Chemistry, USA, v. 69, n. 18, p. 6024-6033, 2004.

28. NACHTIGALL, F. F. ; LAZAROTTO, M. ; CASTELlAnO, e e ; NOME, F . Endo-cavity Complexes between Calix[6]arene Dianions and Aliphatic Ammonium Cations: Structure of a Hexadecylammonium Complex by X-ray Crystallography. Supramolecular Chemistry, England, v. 16, n. 6, p. 453-458, 2004.

29. DOMINGOS, J B ; LONGHINOTTI, e ; BRANDÃO, T A S ; SANTOS, L S ; EBERLIN, M N ; BUNTON, C A ; NOME, F . Reaction of Bis(2,4dinitrophenyl) Phosphate with Hydrazine and Hydrogen Peroxide. Comparing O- and N- Phosphorylation.. Journal of Organic Chemistry, USA, v. 69, p. 7898-7905, 2004.

30. NACHTIGALL，F. F. ; NOME, F ; LAZAROTTO, M. . Mobilidade conformacional de complexos entre calix[4]arenos e aminas: evidências para estruturas exo-calix. Revista Eclética Química, São Paulo, v. 29, n. 1, p. 25-29, 2004.

31. NOME, F ; DOMINGOS, J. B. ; LONGHINOTTI, E. ; MACHADO, V. G. . A Química dos Ésteres de Fosfato. Química Nova, Brasil, v. 26, n. 5, p. 745-753, 2003.

32. NOME, F ; DOMINGOS, J. B. ; LONGHINOTTI, E. ; BUNTON, CA . Reactions of Bis(2,4-dinitrophenyl) Phosphate with Hydroxylamine. Journal of Organic Chemistry, v. 68, p. 7051-7058, 2003.

33. NOME, F ; NACHTIGALL, F. F. ; LAZZAROTTO, M. . Interaction of Calix[4]arene and Aliphatic Amines: A Combined NMR, Spectrophotometric and Conductimetric Investigation. Journal Of The Brazilian Chemical Society, São Paulo, v. 13, n. 3, p. 295-299, 2002. 
34. NOME, R. A.; MARTINEZ, C. M.; NOME, F; FIEDLER, H. D. L.. Theoretical Framework for the Distribution of Trace Metals among the Operationally Defined Speciation Phases of a Sediment. Environmental Toxicology and Chemistry, USA, v. 20, p. 693-697, 2001.

35. NOME, F; ONOFRIO, A. B.; GESSER, J. C. ; JOUSSEF, A. C. . Reactions of $\mathrm{N}$-(O-carboxybenzoyl)-l-leucine. Intramolecular catalysis of amide hydrolysis and imide formation by two carboxy-groups.. Journal of The Chemical SocietyPerkin Transactions 2, Inglaterra, p. 1863-1868, 2001.

36. LAZZAROTTO, M. ; NACHTIGALL, F. F. ; NOME, F . Synthesis of NPhthaloyl Amino Acid para-tert-butylcalix[4]arene Esters. . Journal of The Brazilian Chemical Society, São Paulo, v. 12, p. 255-258, 2001.

37. NOME, F ; BARROS, T. C. ; YUNES, S. ; MENEGON, G. ; CHAIMOVICH, H. ; POLITI, M. J. ; CUCCOVIA, L. G. D. I. M. . Hydrolysis of 1,8 and 2,3 naphthalic anhydrides and the mechanism of cyclization of 1,8-naphthalic acid in aqueous solutions.. Journal of The Chemical Society-Perkin Transactions 2, Inglaterra, p. 2342-2350, 2001.

38. NOME, F ; MACHADO, V. G. ; BUNTON, C A ; ZUCCO, C . Desolvated phosphate ions as acyl acceptors in dipolar aprotic media. A non-enzymatic model for formation of energy-rich acyl phosphates. Journal of The Chemical Society-Perkin Transactions 2, Inglaterra, n. 1, p. 169-173, 2000.

39. LEE, B. S.; NOME, F . Effects of Sulfobetaine-Sodium Decylphosphate Mixed Micelles on Deacylation and Indicator Equilibrium.. Langmuir, USA, v. 16, p. 10131-10136, 2000.

40. NOME, F ; MACHADO, V. G. . Energy-rich phosphate compounds. Química Nova, Brasil, v. 22, n. 3, p. 351-357, 1999.

41. LEHMKUHL, A. ; GANZAROLLI, E. M. ; DESOUZA, I. G. ; NOME, F . A thermostatization system for flow injection analysis applications.. Química Nova, Brasil, v. 22, n. 1, p. 136-137, 1999.

42. NOME, F ; ONOFRIO, A B ; JOUSSEF, A C . A convenient synthesis of optically active N-(o-carboxybenzoyl)-L-amino acids. Synthetic Communications, USA, v. 29, n. 17, p. 3039-3049, 1999.

43. NOME, F ; GAMA, A. A. S. ; MACHADO, J. C. . Avaliação da Pós-Graduação em Química no Brasil, Biênio 96/97. . Química Nova, São Paulo, v. 22, p. 443447, 1999.

44. LAZAROTTO, M. ; NOME, F ; NACHTIGALL, F. F. ; VENCATO, I. . Chiral Lactic Acid And Ethyl Lactate P-Terc-Butylcalix(4)Arene Derivatives. Journal of The Chemical Society-Perkin Transactions 2, EUA, n. 4, p. 995-998, 1998.

45. NACHTIGALL, F. F. ; VENCATO, I. ; LAZAROTTO, M. ; NOME, F . Calix(4)Arene Piperidinium Salt. Acta Crystallographica C, EUA, v. 54, p. 1007-1010, 1998.

46. LIMA, C. F. ; ZANETTE, D. ; NOME, F . The Absence Of Conventional Polymer-Surfactant Interaction Between Sodium Monodecyl Phosphate And Poly(Ethylene Oxide): Conductivity And Kinectic Evidence. Journal of Colloidal and Interface Sci., EUA, v. 187, n. 2, p. 396-400, 1997.

47. LIMA, C. F. ; NOME, F ; ZANETTE, D. . First Evidence Of Poly(Ethilene Oxide) Mixed Sodium Dodecyl Sulfate/Sodium Decyl Phosphate Complexes. Journal of Colloidal and Interface Sci., v. 189, n. 1, p. 174-176, 1997. 
48. YUNES, S. F.; GESSER, J. C.; CHAIMOVICH, H.; NOME, F. Mechanistically Optimized Intramolecular Catalysis In Hydrolysis Of Esteres: Global Changes Involved In Molecular Reactivity. Journal of Physical Organic Chemistry, EUA, v. 10, n. 6, p. 461-465, 1997.

49. MACHADO, V. G. ; NOME, F . Acyl Transfer Reactions In Dipolar Aprotic Medium: Desolvated Phosphate Ion As Acyl Acceptor In The Formation Of Energy-Rich Phosphate Compounds.. Journal of The Chemical SocietyChemical Communications, Inglaterra, v. 19, p. 1917-1918, 1997.

50. GESSER, J. C. ; NOME, F ; YUNES, S. F. ; CLEMENTIM, R. M. . Reações Intramoleculares Como Modelos Não Miméticos de Catálise Enzimática.. Química Nova, Brasil, v. 20, n. 6, p. 631-637, 1997.

51. FOROUdIAN, H. J. ; BUNTON, C. A. ; HOLLAND, P. M. ; NOME, F . The Nuclephillicity Of Bromide Ion In Mixed Cationic Sulfoxide Micelles. Journal of The Chemical Society-Perkin Transactions 2, Inglaterra, n. 4, p. 557-561, 1996.

52. NOME, F; BENNUR, S. C. ; TALAWAR, M. B. ; LADDI, U. V. . Free radical elimination and oxidation of 1,1,1-trichloro-2,2-bis(p-substituted phenyl)ethanes . Indian Journal Of Chemistry Section B Organic Chemistry Including Medicinal Chemistry, India, v. 35, n. 1, p. 74-76, 1996.

53. FROEHNER, S. J. ; NOME, F ; ZANETTE, D. ; BUNTON, C A . Micellarmediated general acid catalyzed acetal hydrolysis. Reactions in comicelles. Journal of The Chemical Society-Perkin Transactions 2, Inglaterra, n. 4, p. 673-676, 1996.

54. LAZAROTTO, M. ; NACHTIGALL, F. F. ; NOME, F . Calixarenos: Receptores Para Reconhecimento Molecular. Química Nova, v. 18, n. 5, p. 444451, 1995.

55. NOME, F ; GESSER, J. C. ; ZUCCO, C. . Kinetics Of The Reaction Of Amines With 1,1,1-Trichloro-4-Methoxy-3-Penten-2-One. Journal of Physical Organic Chemistry, USA, v. 8, n. 2, p. 97-102, 1995.

56. NOME, F ; ZUCCO, C. ; ZANETTE, D. ; MARIN, M. A. B. ; ROMSTED, L. S. . Effect Of Cetyltrimethylammonium Micelles With Bromide, Chloride And Hydroxide Counterions On Rates Of Decomposition Of Para-Subituted The Aryl-2,2,2-Trichloroethanols In Aqueous Naoh. Journal of Physical Chemistry, v. 99, n. 27, p. 10879-10882, 1995.

57. FRESCURA, V. L. ; MARCONI, D. M. O. ; NOME, F ; ZANETTE, D. ; BUNTON, C. ; BLASKÓ, A. . Effects Of Sulfobetaine-Sodium Dodecanoate Micelles On Deacylation And Indicator Equillibrium. Journal of Physical Chemistry, v. 99, n. 29, p. 11494-11500, 1995.

58. RUZZA, A. A. ; ZANETTE, D. ; ROMSTED, L. S. ; NOME, F . Kinectics Evidence For Temperature-Induced Demixing Of A Long Chain Dioxolane In Aqueous Micellar Solutions Of Sodium Dodecyl Sulfate: A New Application Of The Pseudophase Ion Exchange Model. Langmuir, v. 11, n. 7, p. 2393-2398, 1995.

59. NOME, F ; BUNTON, C. A. ; TOLEDO, E. A. ; BLASKÓ, A. ; HOLLAND, P. M. . Sn2 Reactions Of Sulfonate Ester In Mixed Cationic/Phosphine Oxide Micelles. Journal of The Chemical Society-Perkin Transactions 2, Inglaterra, $\mathbf{n}$. 12, p. 2367-2373, 1995.

60. SOUZA, I. G. ; REZENDE, M. C. ; NUERNBERG, L. A. A. ; BELARMINO, A. T. N. ; NOME, F . Construção de Um Viscosímetro Digital. Química Nova, Brasil, v. 17, p. 230-232, 1994. 
61. ANDRADE, J. B. ; SCHORE, H. R. ; NASCIMENTO, M. G. ; GIORDAN, M. ; BROCKSON, T. G. ; BARREIRO, E. J. ; NOME, F . Análise da PósGraduação Em Química No País. Química Nova, v. 18, n. 1, p. 97-98, 1994.

62. SANTOS, S. F. ; ZANETTE, D. ; NOME, F ; REED, W. F. . Fluorescence Evidence For Formation Of Hyaluronate Ion Dodecyltrimethylammonium Bromide Complex. Journal of Colloidal and Interface Sci., v. 164, n. 1, p. 260262, 1994.

63. RUBIO, D. A. ; ZANETTE, D. ; BUNTON, C. ; NOME, F . Effect Of 1-Butanol On Micellization Of Sodium Dodecyl Sulfate On Fluorescence Quenching By Bromide Ion. Langmuir, v. 10, n. 4, p. 1151-1154, 1994.

64. RUBIO, D. ; ZANETTE, D. ; BUNTON, C. ; NOME, F . Acid Hydrolysis Of PMethoxybenzaldehyde O-Acyloxime In 1-Butanol Modiffied Micelles Of Sodium Dodecyl Sulfate. Langmuir, v. 10, n. 4, p. 1155-1159, 1994.

65. MARCONI, D. M. O. ; FRESCURA, V. L. A. ; ZANETTE, D. ; BUNTON, C. ; NOME, F . Nucleophylically Assisted Deacylation In Sodium Dodecanoate And Dodecyl Sulfate Micelles. Quantitative Evidence On Pre-Micellar Complexes. Journal of Physical Chemistry, v. 98, p. 12415-12419, 1994.

66. NOME, F ; ZANETTE, D. ; RUZZA, A. A. . Quantitative Treatment Of Ketal Hydrolysis In Aqueous Solutions Containing Polymer-Surfactant Complexes Using A Pseudophase Kinetic Model. Journal of Physical Chemistry, EUA, v. 98, p. 12361-12366, 1994.

67. FROEHNER, S. J. ; NOME, F ; ZANETTE, D. ; BUNTON, C. A. . Micellar Mediated General Acid Catalyzed Acetal Hydrolysis. Reactions In Comicelles. Journal of The Chemical Society-Perkin Transactions 2, n. 4, p. 673-676, 1994.

68. CLIFFORD, A. B. ; NOME, F ; WRIGHT, S. ; HOLLAND, P. M. ; NOME, F. . Sn2 Reactions Of A Sulfonate Ester In Mixed Cationic/Nonionic Micelles. Langmuir, Estados Unidos, v. 09, n. 01, p. 117-120, 1993.

69. BERTONCINI, C. R. A. ; NEVES, M. F. S. ; BUNTON, C. ; NOME, F . Effects Of 1-Butanol Modified Micelles On Sn2 Reactions In Mixed-Ion Systems. Langmuir, Estados Unidos, v. 09, n. 06, p. 1274-1279, 1993.

70. RUZZA, A. A. ; NOME, F ; WALTER, M. R. ; NOME, F. ; ZANETTE, D. . Effects Of Monoalkyl Phosphate Surfactants Upon Acid Hydrolysis Of Dioxolanes. Journal of Physical Chemistry, Estados Unidos, v. 96, n. 03, p. 1463-1467, 1992.

71. FERREIRA, L. C. M. ; NOME, F ; ZUCCO, C. ; NOME, F. ; ZANETTE, D. . Pseudophase Ion-Exchange Model Applied To Kinetics In Aqeous Micelles Under Extreme Conditions. A Simple Modification. Journal of Physical Chemistry, Estados Unidos, v. 96, n. 22, p. 9058-9061, 1992.

72. NASCIMENTO, M. G. ; LEZCANO, M. A. ; NOME, F . Micellar Effects On The Hydrolysis of 2,2,2-Trichloro-1-Phenylethanone. Journal of Physical Chemistry, Estados Unidos, v. 96, n. 13, p. 5537-5540, 1992.

73. BUNTON, C A ; NOME, F ; QUINA, F H ; ROMSTED, L. S. . Ion Binding And Reactivity At Charged Aqueous Interfaces - Accounts Of Chemical Research, EUA, v. 24, n. 12, p. 357-364, 1991.

74. NOME, F ; FRESCURA, V. L. A. ; ZANETTE, D. ; REZENDE, M. C. . Effect Of Micelles On The Kinetic Stability Of The Co-C Bond In Benzycobalamin.. Bol. Soc. Chil. Quim., v. 35, n. 1, p. 89-96, 1990.

75. CHANG, S. A. ; ZANETTE, D. ; NOME, F . Application Of The Pseudophase Ion Exchange Model To Kinetics Im Microemulsion of Anionic Detergents.. Journal of Physical Chemistry, EUA, v. 94, n. 1, p. 356-361, 1990. 
76. BERTONCINI, C. R. A. ; NOME, F ; CERICHELLI, G. ; BUNTON, C A . Effect Of 1-Butanol Upon Sn2 Reactions In Cationic Micelles - A Quantitative Treatment. Journal of Physical Chemistry, EUA, v. 94, n. 15, p. 5875-5878, 1990.

77. BUNTON, C A ; COWELL, C. P. ; NOME, F ; ROMSTED, L. S. . Anomalous Salt Effects On A Micellar-Mediated Reaction Of Bromide Ion. Journal of Physical Organic Chemistry, EUA, v. 3, n. 4, p. 239-247, 1990.

78. WENDHAUSSEN, R. ; ZAMPIRON, E. ; VIANNA, J. F. ; ZUCCO, C ; REZENDE, M. C. ; NOME, F . Hydration Of 2,2-Dichloro-1-Arylethanones In Water And Tetrahydrofuran Water Mixtures. Journal of Physical Organic Chemistry, EUA, v. 3, n. 2, p. 89-94, 1990.

79. NEVES, M. F. S. ; ZANETTE, D. ; QUINA, F. ; MORETTI, M. T. ; NOME, F . Origin Of The Apparent Breakdown Of The Pseudophase Ion Exchange Model for Micellar Catalysis with Reactive Counterion Surfactants. Journal of Physical Chemistry, EUA, v. 93, n. 4, p. 1502-1505, 1989.

80. SALIM, J. R. ; NOME, F ; REZENDE, M. C. . 1,1,1-Trichloropropanone: A Mild Selective Acetylating Agent.,2 - Trichloro- 1-Arylethanones.. Synthetic Communications, EUA, v. 19, n. 7, p. 1181-1187, 1989.

81. DRUZIAN, J. ; ZUCCO, C. ; REZENDE, M. C. ; NOME, F . Aminolysis Of 2,2,2-Trichloro-1-Arylethanones In Aprotic Solvents.. Journal of Organic Chemistry, EUA, v. 54, n. 20, p. 4767-4771, 1989.

82. HESS, S. C. ; NOME, F ; ZUCCO, C. ; REZENDE, M. C. . The Reactions Of 2,2,2-Trichloro-1-Phenythanone With O,C And S Nucleophiles.. Synthetic Communications, EUA, v. 19, n. 17, p. 3037-3045, 1989.

83. UIEARA, M. ; ZUCCO, C. ; ZANETTE, D. ; REZENDE, M. C. ; NOME, F . Kinetic And Thermodynamic Parameters For The Alcoholysis Of 2,2,2Trichloro-1-Arylethanones.. Journal of The Chemical Society-Perkin Transactions 2, LONDON, n. 2, p. 175-179, 1987.

84. ZANETTE, D. ; LEITE, M. R. ; REED, W. ; NOME, F . Intrinsic Basicity Constant Of 10-Phenyl-10-Hydroxyiminodecanoate In Aqueous Solutions Of Hexadeciltrimethylammonium Bromide - Effects of Salts and Detergent Concentration. Journal of Physical Chemistry, EUA, v. 91, n. 8, p. 2100-2102, 1987.

85. BRITO, M. A. ; NOME, F ; REZENDE, M. C. ; ZANETTE, D. ; NOME, F. . Hidrolise Basica de Acetilcobalamina. Química Nova, Brasil, p. 0-0, 1987.

86. ZUCCO, C. ; NOME, F ; LIMA, C. F. ; REZENDE, M. C. ; VIANNA, J. F. ; NOME, F. . Kinetics Of The Thermolysis Of Para Substituted Benzylcobalamins And Derivatives.. Canadian Journal of Chemistry, CANADA, v. 65, n. 9, p. 2095-2099, 1987.

87. REBELO, R. A. ; REZENDE, M. C. ; NOME, F ; ZUCCO, C. . The Use Of 2,2,2-Trichloro-1-Arylethanones As Benzoylating.. Synthetic Communications, EUA, v. 17, n. 14, p. 1741-1748, 1987.

88. ZUCCO, C. ; LIMA, C. F. ; REZENDE, M. C. ; VIANNA, J. F. ; NOME, F . Mechanistic Studies On The Basic Hydrolysis Of 2,2,2-Trichloro-1Arylethanones. Journal of Organic Chemistry, EUA, v. 52, n. 24, p. 5356-5359, 1987.

89. NASCIMENTO, M. G. ; MIRANDA, S. A. F. ; NOME, F . The Use Of Reactive Counterion Type Micel For The Determination Of Selectivity Coefficients.. Journal of Physical Chemistry, EUA, v. 90, n. 15, p. 3366-3368, 1986. 
90. ARMSTRONG, D. W. ; NOME, F ; SPINO, L. A. ; GOLDEN, T. D. . Efficient Detection And Evaluation Of Cyclodextrin Multiple Complex-Formation. Journal of the American Chemical Society, EUA, v. 108, n. 7, p. 1418-1421, 1986.

91. NOME, F. ; NOME, F ; POLITTI, M. J. ; REED, W. ; FENDLER, J. H. . Cleft Formation Upon Polymerization Of Surfactant Vesicles.. Journal of the American Chemical Society, EUA, v. 106, n. 26, p. 8086-8093, 1985.

92. RAFAELOFF, R. ; TRICOT, Y. M. ; NOME, F ; FENDLER, J. H. . Colloidal Catalyst Coated Semiconductors In Surfactant Vesicles: In Situ Generation Of Rh Coated CdS Particles in Dioctadecyldimethylammonium Halide Surfactant Vesicles and their Utilization in Photosensitized Charge Separation and Hydrogen Generation. Journal of Physical Chemistry, v. 89, n. 3, p. 533-537, 1985.

93. GONSALVES, M. ; PROBST, S. ; REZENDE, M. C. ; NOME, F ; ZUCCO, C. ; ZANETTE, D. . Failure Of The Pseudophase Model In The Acid Catalyzed Hydrolysis Of Acetals And P-Methoxybenzaldoxime Esters in the Presence of an Anionic Micelle. Journal of Physical Chemistry, EUA, v. 89, n. 7, p. 11271130, 1985.

94. SILVA, I. A. ; ZANETTE, D. ; NOME, F . Reactions In Microemulsions, The Dehydrochlorintaion Of D D T And Derivatives.. Atualidades de FísicoQuímica Orgânica, n. 1, p. 123-136, 1985.

95. RAFAELOFF, R. ; TRICOT, Y. M. ; NOME, F ; TUNDO, P. ; FENDLER, J. H. . Incorporation Of A Recyclable Surface-Active Electron-Donor In Synthetic Vesicles - Application To Photosensitized Hydrogen Formation By Vesicle-Stabilized Rh-Coated Colloidal Cds Particles . Journal of Physical Chemistry, EUA, v. 89, n. 7, p. 1236-1238, 1985.

96. SERRANO, J. ; MUCINO, S. ; MILLAN, S. ; REYNOSO, R. ; FUCUGAICHI, L. A. ; REED, W. ; NOME, F ; TUNDO, P. ; FENDLER, J. H. . Polymerized Surfactant Vesicles - Determinations Of Rates And Degrees Of Polymerization In Vesicles Prepared From Styrene-Containing Surfactants . Macromolecules, EUA, v. 18, n. 10, p. 1999-2005, 1985.

97. HERVE, P. ; NOME, F ; FENDLER, J. H. . Magnetic Effects On ChemicalReactions In The Absence Of Magnets - Effects Of Surfactant Vesicle Entrapped Magnetite Particles On Benzophenone Photochemistry . Journal of the American Chemical Society, ÙSA, v. 106, n. 26, p. 8291-8292, 1984.

98. STADLER, E. ; ZANETTE, D. ; REZENDE, M. C. ; NOME, F . KineticBehavior Of Cetyltrimethylammonium Hydroxide - The Dehydrochlorination Of 1,1,1-Trichloro-2,2-Bis(P-Chlorophenyl)Ethane And Some Of Its Derivatives . Journal of Physical Chemistry, EUA, v. 88, n. 9, p. 1892-1896, 1984.

99. LINS, H. S. E. ; NOME, F ; REZENDE, M. C. ; SOUSA, I. . Kinetics Of The Decomposition Of 1-Aryl-2,2,2-Trihalogenoethanols In Aqueous Base. Journal of The Chemical Society-Perkin Transactions 2, Inglaterra, n. 9, p. 1521-1526, 1984.

100. REZENDE, M. C. ; RUBIRA, A. F. ; FRANCO, C. ; NOME, F . Effect Of Normal And Functional Micelles In Elimination-Reactions Of Polyhalogenated Pesticides. Journal of The Chemical Society-Perkin Transactions 2, Inglaterra, n. 8, p. 1075-1078, 1983. 
101. NOME, F ; REZENDE, M. C. ; DE SOUZA, N. S. . Formation Of TransStilbenes From 1,1-Dichloro-2,2-Diarylethanes - A New Cobaloxime-Mediated Carbenoid Rearrangement . Journal of Organic Chemistry, EUA, v. 48, n. 26, p. 5357-5359, 1983.

102. NOME, F ; RUBIRA, A. F. ; FRANCO, C. ; IONESCU, L. G. . Limitations Of The Pseudophase Model of Micellar Catalysis. The Dehydrochlorination Of 1,1,1-Trichloro-2,2-Bis(P-Chlorophenyl)Ethane And Some of Its Derivates.. Journal of Physical Chemistry, USA, v. 86, n. 10, p. 1881-1885, 1982.

103. ARMSTRONG, D. W. ; NOME, F . Partitioning Behavior Of Solutes Eluted With Micellar Mobile Phases In Liquid-Chromatography. Analytical Chemistry, EUA, v. 53, n. 11, p. 1662-1666, 1981.

104. NOME, F ; ERBS, W. ; CORREIA, V. R. . Kinetic And Thermodynamic Study Of The Base-Catalyzed Oxidative Cleavage Of 1,1-Bis(Para-Chlorophenyl)2,2,2-Trichloroethanol. Journal of Organic Chemistry, EUA, v. 46, n. 19, p. 3802-3804, 1981.

105. NOME, F ; SCWINGEL, E. W. ; IONESCU, L. G. . Micellar Effects On The Base-Catalyzed Oxidative Cleavage Of A Carbon-Carbon Bond In 1,1-Bis(PChlorophenyl)-2,2,2- Trichlorethanol. Journal of Organic Chemistry, EUA, v. 45, n. 4, p. 705-710, 1980 .

106. NOME, F; LARANJEIRA, M C M ; ARMSTRONG, D. W. . Reactions Of Vitamin-B12r With Polyhalogenated Hydrocarbon Pesticides. Bioorganic Chemistry, EUA, v. 9, n. 3, p. 313-317, 1980.

107. NOME, F ; ZANETTE, D. . Mechanistic Study Of The Reaction Of VitaminB12s With 1,1-Dichloro-2,2-Bis Para-Chlorophenyl)Ethane . Canadian Journal of Chemistry, Canada, v. 58, n. 23, p. 2402-2405, 1980.

108. ZANETTE, D. ; NOME, F . Vitamin-B12s Catalyzed Dechlorination Of 1,1Dichloro-2,2-Bis(P-Chlorophenyl)Ethane - Novel Synthesis Of Substituted Stilbenes. Journal of Organic Chemistry, EUA, v. 44, n. 13, p. 2308-2309, 1979.

109. CORRELL, G. D. ; CHESER, R. N. ; NOME, F ; FENDLER, J. H. . Fluorescence Probes In Reversed Micelles Luminescence Intensities, Lifetimes, Quenching, Energy-Transfer, And Depolarization Of Pyrene Derivatives In Cyclohexane In Presence Of Dodecylammonium Propionate Aggregates . Journal of the American Chemical Society, EUA, v. 100, n. 4, p. 1254-1262, 1978.

110. TSUJII, K. ; SUNAMOTO, J. ; NOME, F ; FENDLER, J. H. . Concentration Dependent Ground And Excited-State Behavior Of Dodecylammonium Pyrene-1-Butyrate In Ethanol And Benzene . Journal of Physical Chemistry, EUA, v. 82, n. 4, p. 423-429, 1978.

111. NOME, F ; KANO, K. ; FENDLER, J. H. . Interaction Of Vitamin-B12a With 8-Azaguanine And 6-Mercaptopurine - Kinetic And Thermodynamic Characterizations. Journal of the Chemical Society, Dalton Transactions, Inglaterra, n. 10, p. 1226-1232, 1978.

112. ROBINSON, G. C. ; NOME, F ; FENDLER, J. H. . Effects Of Surfactants On Cobalamin Dependent Methyl Transfer - Influence Of Aqueous And Reversed Micelles On Interaction Of Mercuric Ion With Methylcobalamin . Journal of the American Chemical Society, EUA, v. 99, n. 15, p. 4969-4976, 1977.

113. NOME, F ; ESCABIPEREZ, J. R. ; FENDLER, J. H. . Energy-Transfer In Micellar Systems - Steady-State And Time Resolved Luminescence Of Aqueous Micelle Solubilized Naphthalene And Terbium Chloride. Journal of the American Chemical Society, EUA, v. 99, n. 24, p. 7749-7754, 1977. 
114. NOME, F ; FENDLER, J. H. . Effects Of Surfactants On Interaction Of Vitamin-B12a With Cysteine And N-Alkanoylcysteines In Water And In Benzene - Influence Of Aqueous Micelles And Solvent Restrictions. Journal of the American Chemical Society, EUA, v. 99, n. 5, p. 1557-1564, 1977.

115. ARMSTRONG, D. W. ; NOME, F ; FENDLER, J. H. ; NAGYVARY, J. . Novel Prebiotic Systems - Nucleotide Oligomerization In Surfactant Entrapped Water Pools . Journal of Molecular Evolution, EUA, v. 9, n. 3, p. 213-223, 1977.

116. NOME, F ; CHANG, S. A. ; ZANETTE, D. . Indicators in Benzene in Presence of Dodecylammonium Propionate. Journal of The Chemical Society-Faraday Transactions - 2, Londres, v. 72, p. 296-302, 1976.

117. NOME, F ; FENDLER, J. H. . Interaction Of Cysteine With Vitamin-B12a Kinetic And Thermodynamic Investigations . Journal of the Chemical Society, Dalton Transactions, EUA, n. 13, p. 1212-1219, 1976.

118. NOME, F; CHANG, S. A.; FENDLER, J. H. . Indicators In Benzene In Presence Of Polyoxyethylene(6) Nonylphenol. Journal of Colloidal and Interface Sci., EUA, v. 56, n. 1, p. 146-158, 1976.

119. NAGYVARY, J. ; HARVEY, J. A. ; NOME, F ; ARMSTRONG, D. W. ; FENDLER, J. H. . Novel Prebiotic Model Systems - Interactions Of Nucleosides And Nucleotides With Aqueous Micellar Sodium Dodecanoate . Precambrian Research, EUA, v. 3, n. 6, p. 509-516, 1976.

120. HUMERES, E; NOME, F; AGUIRRE, R.. Reaction Of Some Carbohydrates And Related Compounds With 4-Amino-3-Hydrazino-5-Mercapto-1,2,4Triazole . Carbohydrate Research, EUA, v. 46, n. 2, p. 284-288, 1976.

121. FENDLER, J. H. ; NOME, F ; NAGYVARY, J. . Compartmentalization Of Amino-Acids In Surfactant Aggregates - Partitioning Between Water And Aqueous Micellar Sodium Dodecanoate And Between Hexane And Dodecylammonium Propionate Trapped Water In Hexane. Journal of Molecular Evolution, EUA, v. 6, n. 3, p. 215-232, 1975.

122. NOME, F; FENDLER, J. H. ; VANWOERT, H. C. . Effects Of Surfactants On Ligand-Exchange Reactions In Vitamin-B12a In Water And In Benzene Influence Of Aqueous Micelles And Of Solvent Restrictions. Journal of the American Chemical Society, EUA, v. 96, n. 21, p. 6745-6753, 1974.

123. NOME, F; HUMERES, E. The Hydrolysis of the Glyceraldehide-3-phosphate and related compounds. Bol. Soc. Chil. Quim., Santiago, v. 18, p. 84-84, 1972.

124. NOME, F; CHAIMOVICH, H. . Purification and Properties of an Acid Phosphatase from Bovine Brain. Arch. Biochem. Biophys., England, v. 139, p. 9-16, 1970.

125. NOME, F; HUMERES, E; ALBORNOZ, C. La hidrólisis del Gliceraldehido-3fosfato. Archivos de Biologia y Medicina Experimentales, Santiago, v. 7, p. 1-2, 1970.

ACKNOWLEDGEMENT. Financial support received by LGI from Sarmisegetusa Research Group, Santa Fe, New Mexico, USA is gratefully acknowledged. 